\title{
Front Matter: Volume 9455
}

, "Front Matter: Volume 9455," Proc. SPIE 9455, Chemical, Biological, Radiological, Nuclear, and Explosives (CBRNE) Sensing XVI, 945501 (10 June 2015); doi: 10.1117/12.2184323

SPIE. Event: SPIE Defense + Security, 2015, Baltimore, MD, United States 


\title{
PROCEEDINGS OF SPIE
}

\section{Chemical, Biological, Radiological, Nuclear, and Explosives (CBRNE) Sensing XVI}

\author{
Augustus W. Fountain III \\ Editor
}

21-23 April 2015

Baltimore, Maryland, United States

Sponsored and Published by

SPIE

Volume 9455 
The papers included in this volume were part of the technical conference cited on the cover and title page. Papers were selected and subject to review by the editors and conference program committee. Some conference presentations may not be available for publication. The papers published in these proceedings reflect the work and thoughts of the authors and are published herein as submitted. The publisher is not responsible for the validity of the information or for any outcomes resulting from reliance thereon.

Please use the following format to cite material from this book:

Author(s), "Title of Paper," in Chemical, Biological, Radiological, Nuclear, and Explosives (CBRNE) Sensing XVI, edited by Augustus W. Fountain III, Proceedings of SPIE Vol. 9455 (SPIE, Bellingham, WA, 2015) Article CID Number.

ISSN: 0277-786X

ISBN: 9781628415711

Published by

SPIE

P.O. Box 10, Bellingham, Washington 98227-0010 USA

Telephone +1 3606763290 (Pacific Time) · Fax +1 3606471445

SPIE.org

Copyright (@ 2015, Society of Photo-Optical Instrumentation Engineers.

Copying of material in this book for internal or personal use, or for the internal or personal use of specific clients, beyond the fair use provisions granted by the U.S. Copyright Law is authorized by SPIE subject to payment of copying fees. The Transactional Reporting Service base fee for this volume is $\$ 18.00$ per article (or portion thereof), which should be paid directly to the Copyright Clearance Center (CCC), 222 Rosewood Drive, Danvers, MA 01923. Payment may also be made electronically through CCC Online at copyright.com. Other copying for republication, resale, advertising or promotion, or any form of systematic or multiple reproduction of any material in this book is prohibited except with permission in writing from the publisher. The CCC fee code is 0277-786X/15/\$18.00.

Printed in the United States of America.

Publication of record for individual papers is online in the SPIE Digital Library.

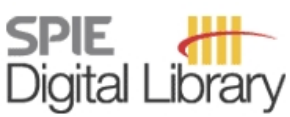

SPIEDigitalLibrary.org

Paper Numbering: Proceedings of SPIE follow an e-First publication model, with papers published first online and then in print. Papers are published as they are submitted and meet publication criteria. A unique citation identifier (CID) number is assigned to each article at the time of the first publication. Utilization of CIDs allows articles to be fully citable as soon as they are published online, and connects the same identifier to all online, print, and electronic versions of the publication. SPIE uses a six-digit CID article numbering system in which:

- The first four digits correspond to the SPIE volume number.

- The last two digits indicate publication order within the volume using a Base 36 numbering

system employing both numerals and letters. These two-number sets start with 00, 01, 02, 03, 04, $05,06,07,08,09,0 A, 0 B \ldots$ OZ, followed by 10-1Z, 20-2Z, etc.

The CID Number appears on each page of the manuscript. The complete citation is used on the first page, and an abbreviated version on subsequent pages. 


\title{
Contents
}

\author{
vii Authors \\ ix Conference Committee \\ xi Introduction
}

\section{RADIOLOGICAL DETECTION}

945502 Neutron spectroscopy using III-V semiconductor scintillators [9455-1]

945503 Subwavelength films for standoff radiation dosimetry [9455-2]

945504 Dehydration of uranyl nitrate hexahydrate to the trihydrate under ambient conditions as observed via dynamic infrared reflectance spectroscopy [9455-3]

945505 Effects of sample preparation on the infrared reflectance spectra of powders [9455-4]

945506 Use of CLYC spectrometer in counter-terrorism applications [9455-5]

\section{BIOLOGICAL DETECTION}

945507 Quartz crystal microbalance biosensor for rapid detection of aerosolized microorganisms [9455-10]

945508 Standoff detection and classification procedure for bioorganic compounds by hyperspectral laser-induced fluorescence (Best Paper Award 2nd Place) [9455-11]

945509 Bioaerosol detection and classification using dual excitation wavelength laser-induced fluorescence [9455-12]

$94550 \mathrm{~A}$ Analysis of protective antigen peptide binding motifs using bacterial display technology [9455-13]

9455 OB Multisense chip: continuously working air monitoring system: An integrated system for the detection of airborne biological pathogens on molecular and immunological level [9455-14]

\section{ALGORITHMS FOR CBRNE SENSING}

9455 OD Bio-inspired digital signal processing for fast radionuclide mixture identification [9455-17]

$9455 \mathrm{OE}$ Single-wavelength lidar retrieval algorithm of particulate matter concentration using CELiS (Compact Eyesafe Lidar System) a $1.5 \mu \mathrm{m}$ elastic lidar system [9455-18] 
9455 OF Maximum discrimination approach for classification of nearly identical signatures [9455-19]

9455 OG Non-specific sensor arrays for chemical detection [9455-20]

$9455 \mathrm{OH}$ Removal of nonresonant background in MCARS spectra using Fourier filtering [9455-21]

9455 Ol Trace explosives detection using photo-thermal infrared imaging spectroscopy (PT-IRIS): theory, modeling, and detection algorithms [9455-22]

\section{CHEMICAL SENSING I}

$94550 \mathrm{~K}$ New plasmonic materials and fabrication tools for near- and mid-infrared sensing and spectroscopy (Invited Paper, Best Paper Award 1 ${ }^{\text {st }}$ Place) [9455-24]

9455 OL Detection of chemical clouds using widely funable quantum cascade lasers [9455-25]

9455 OM Detecting liquid contamination on surfaces using hyperspectral imaging data [9455-26]

9455 ON The development of a wide-field, high-resolution UV Raman hyperspectral imager [9455-27]

945500 Advanced shortwave infrared and Raman hyperspectral sensors for homeland security and law enforcement operations [9455-28]

\section{EXPLOSIVES SENSING}

$94550 Q$ Single-shot stand-off detection of explosives precursors using UV coded aperture Raman spectroscopy [9455-30]

9455 OR Advances in sublimation studies for particles of explosives [9455-32]

\section{CHEMICAL SENSING II}

9455 OS Experimental examination of ultraviolet Raman cross sections of chemical warfare agent simulants [9455-33]

9455 OT Photoacoustic chemical sensing: layered systems and excitation source analysis [9455-34]

9455 OU Cooperative use of standoff and UAV sensors for CBRNE detection [9455-35]

9455 OV Detection of munitions grade g-series nerve agents using Raman excitation at $1064 \mathbf{n m}$ [9455-36]

\section{CHEMICAL SENSING III}

9455 OW A molecularly imprinted polymer (MIP)-coated microbeam MEMS sensor for chemical detection [9455-37]

iv 
$94550 X \quad$ A study of single-beam femtosecond MCARS in trace material detection [9455-38]

9455 OY Differential excitation spectroscopy for detection of chemical threats: DMMP and thiodiglycol [9455-39]

$9455 \mathrm{OZ}$ Breadboard sized photo-acoustic spectroscopy system using an FPGA based lock-in amplifier [9455-40] 
Proc. of SPIE Vol. $9455945501-6$

Downloaded From: https://www.spiedigitallibrary.org/conference-proceedings-of-spie on 26 Apr 2023 Terms of Use: https://www.spiedigitallibrary.org/terms-of-use 


\section{Authors}

Numbers in the index correspond to the last two digits of the six-digit citation identifier (CID) article numbering system used in Proceedings of SPIE. The first four digits reflect the volume number. Base 36 numbering is employed for the last two digits and indicates the order of articles within the volume. Numbers start with 00, 01, 02, 03, 04, 05, 06, 07, 08, 09, OA, OB...0Z, followed by 10-1Z, 20-2Z, etc.

\author{
Abb, Martina, OK \\ Abrishami, Tara, OR \\ Aleksejev, Valeri, 08 \\ Alvine, Kyle J., 03 \\ Andrews, H. R., 06 \\ Angel, S. Michael, ON \\ Arbouet, Arnaud, OK \\ Babichenko, Sergey, 08 \\ Becker, Holger, OB \\ Bennett, Wendy D., 03 \\ Bernacki, Bruce E., 03 \\ Beshay, Manal, OU \\ Bichler, O., OD \\ Bird, Alan W., OE \\ Black, Leo-Jay, OK \\ Blake, Thomas A., 05 \\ Bobin, C., OD \\ Boden, Stuart A, OK \\ Bowman, Sherrie S., OX \\ Braver, Carolyn S., 05 \\ Buck, Edgar C., 04 \\ Byers, Jeff, Ol \\ Cohn, David B., OM \\ Cox, Jason M., OY \\ Croteau, Philly, OU \\ Currie, John F., 02 \\ de Groot, C.H., OK \\ Deutsch, Erik R., OL \\ Dorsey, Brandi L., OA \\ Duschek, Frank, 08 \\ Emge, Darren K., OF \\ Farka, Zdeněk, 07 \\ Farley, Vincent, OM \\ Fischbach, Thomas, 08 \\ Fischer, Thomas, OR \\ Forland, Brenda M., 05 \\ Furstenberg, Robert, OI, OR \\ Gagnon, Marc-André, OM \\ Gardner, Charles W., 00 \\ Gärtner, Claudia, OB \\ Giza, Mark M., OZ \\ Gomer, Nathaniel R., 0N, 00 \\ Goyal, Anish K., OL \\ Gradmark, Per-Åke, 09 \\ Guardala, Noel A., 02 \\ Handke, Jürgen, 08 \\ Harrison, Paul, OY \\ Hausmann, Anita, 08 \\ Hedborg, Julia, 09
}

Hiller, Tobias, OW

Hawatsch, Nadine, $\mathrm{OB}$

Hoffland, Soren, OV

Holthoff, Ellen L., OT, OW, OZ

Hunter, Boyd V., OY

Ing, $\mathrm{H} ., \mathrm{O} 6$

Johnson, Kevin, OG

Johnson, Timothy J., 04, 05

Jonsson, Per, 09

Kay, Steven, OF

Kendziora, Christopher A., OI, OR

Kim, Eunja, 04

Klemm, Richard, OB

Klueva, Oksana, 00

Koslowsky, M. R., 06

Kotidis, Petros, OL

Kovár, David, 07

Kullander, F., OS

Landström, Lars, 09, OS

Larsson, Anders, 09

Lav, Marvin, OU

Lemon, Robert, $\mathrm{OE}$

Li, Lily, OW

Lourenço, V., OD

Lundén, H., OS

Manegold, David, OU

Marcus, Logan S., OT

Marinelli, William J., OU

Mathur, Veerendra K., 02

Mausolf, Edward J., 04

Mazurenko, Alexander, OL

McGill, R. Andrew, OI, OR

McNamara, Bruce K., 04

Meier, David E., 04

Miller, Michael A., OY

Minor, Christian, OG

Moche, Christian, $\mathrm{OB}$

Moore, Kori D., OE

Mott, David R., OR

Mulhall, Phil, OU

Muskens, Otto L., OK

Myers, Tanya L., 05

Nelson, Matthew P., ON, 00

Nguyen, Viet, OI, OR

Nordberg, M., OQ

Norman, Mark, OL

Östmark, H., OQ

Papantonakis, Michael R., OI, OR

Pardoe, Ian, OV 
Pargmann, Carsten, 08

Pellegrino, Paul M., OH, OT, OX, OZ

Poryvkina, Larisa, 08

Rentz Dupuis, Julia, OU

Roberson, Stephen D., OH, OX

Roy, Eric, OV

Sarkes, Deborah A., OA

Schattschneider, Sebastian, OB

Schemer-Kohrn, Alan, 03

Schill, John F., OZ

Schmit, Thomas, OU

Skládal, Petr, 07

Smith, M. B., 06

Sobolev, Innokenti, 08

Stratis-Cullum, Dimitra N., OA

Su, Yin-Fong, 05

Suter, Jonathan D., 03

Svanqvist, M., $0 Q$

Sweet, Lucas E., 04

Thevenin, M., OD

Thiam, C., OD

Turner, Kimberly L., OW

Walters, William P., OY

Wang, Yudong, OK

Warren, Russell E., OM

Wästerby, Pär, 09, OS

Weck, Philippe F., 04

Wensman, Johnathan D., 02

Wilcox, Phillip G., OV

Wojcik, Michael, OE

Ye, Jim, OL

Zafiriou, Kostas, OL

Zhu, Ninghui, OL 


\title{
Conference Committee
}

\author{
Symposium Chair
}

Nils R. Sandell Jr., Strategic Technology Office, DARPA

(United States)

Symposium Co-chair

David A. Logan, BAE Systems (United States)

Conference Chair

Augustus Way Fountain III, U.S. Army Edgewood Chemical Biological Center (United States)

Conference Program Committee

Sylvie Buteau, Defence Research and Development Canada, Valcartier (Canada)

James P. Carney, Sandia National Laboratories (United States)

Christopher C. Carter, Johns Hopkins University Applied Physics Laboratory (United States)

Darren K. Emge, U.S. Army Edgewood Chemical Biological Center (United States)

Jason A. Guicheteau, U.S. Army Edgewood Chemical Biological Center (United States)

Eric J. Houser, U.S. Department of Homeland Security (United States)

Chris R. Howle, Defence Science and Technology Laboratory (United Kingdom)

Harry Ing, Bubble Technology Industries, Inc. (Canada)

Timothy J. Johnson, Pacific Northwest National Laboratory (United States)

Aaron LaPointe, U.S. Army Night Vision \& Electronic Sensors Directorate (United States)

Paul M. Pellegrino, U.S. Army Research Laboratory (United States) James Placke Jr., Y-12 National Security Complex (United States) Cynthia R. Swim, U.S. Army Edgewood Chemical Biological Center (United States)

Anna Tedeschi, Strategic Analysis, Inc. (United States) and U.S. Department of Homeland Security (United States)

Steven W. Waugh, Defense Threat Reduction Agency (United States) 
Session Chairs

1 Radiological Detection

Harry Ing, Bubble Technology Industries, Inc. (Canada)

3 Biological Detection

Cynthia R. Swim, U.S. Army Edgewood Chemical Biological Center (United States)

$4 \quad$ Algorithms for CBRNE Sensing

Darren K. Emge, U.S. Army Edgewood Chemical Biological Center (United States)

5 Chemical Sensing I

Christopher R. Howle, Defence Science and Technology Laboratory (United Kingdom)

6 Explosives Sensing

Aaron LaPointe, U.S. Army Night Vision \& Electronic Sensors Directorate (United States)

7 Chemical Sensing II

Chris R. Howle, Defence Science and Technology Laboratory (United Kingdom)

8 Chemical Sensing III

Augustus Way Fountain III, U.S. Army Edgewood Chemical Biological Center (United States) 


\section{Introduction}

Perhaps it was providence, or just good timing, that the 100th Anniversary of the first use of industrialized gases occurred in the middle of the 16th meeting of the CBRNE Sensing Conference: part of the 2015 SPIE Defense, Security + Sensing Symposium. Despite the continued restrictions on travel and conference attendance, primarily from government participants, the CBRNE Conference was well attended and provided a unique forum where novel chemical and explosives sensing, bio-detection, and nuclear and radiological detection technologies and methods were presented over three days.

This year several themes emerged that define some of the most interesting presentations:

- Small, portable platforms: smartphone spectrometers

- Multi-functional materials and nanocomposites

- Complex, multi-pulse spectroscopy

Smartphones are proving a popular platform for hand-held spectroscopy. Smartphone cameras developed for producing high pixel-count images and operating under low-light conditions have proven sufficient for: fluorescence microscopy, colorimetric spectroscopy of colored liquids in enzyme linked immunosorbent assays, and aerosol particle counting. The use of a smartphonebased platform provides substantial usability benefits including advanced userinterface and data-processing algorithms, and services such as cloud storage, geographic information system-tagging, and remote expert analysis.

New rationally-designed materials to improve chemical detection were described, but they were not all equally promising. In one of the best presentations, Dr. Otto Muskens provided a very informative talk on the use of plasmonics for the enhancement of electromagnetic fields around metallic nanostructures and demonstrated surface-enhanced infrared spectroscopy using arrays of indium tin oxide plasmonic nanoantennas. The combination of label-free infrared spectroscopy with the versatility of doped metal oxides has the potential of opening up new applications in sensing and spectroscopy, for example, as multifunctional transparent electrodes, catalysts, or electrically or optically controllable plasmonic devices.

Similarly, several inherently complex, multi-pulse spectroscopic techniques were highlighted and show enormous potential for enhanced sensitivity and interference rejection. Multiplex Coherent Anti-Stokes Raman spectroscopy (MCARS) has been used to create a complete Raman spectrum of a material of interest in milliseconds. However, these MCARS spectra often embedded in a nonresonant background (NRB) that reduces the ability to use those spectra to 
positively identify the material of interest. ARL presented several algorithms for NRB removal. However, a subsequent MCARS presentation by Dr. Paul Pellegrino indicated that MCARS is an inherently difficult technique and that is not quite ready for prime time analysis of unknowns.

Once again I want to thank my committee who really makes this conference happen. There is no way I could review all the abstracts and proceedings papers or host all the sessions without them. I am confident that this conference remains the most important means of bringing together the leaders in the field of CBRNE sensing from every sector; government, academia and industry. I am already excited about next year's conference and the new developments it will report on.

Augustus W. Fountain III 